УДК 330

\title{
ПЕДАГОГИЧЕСКИЕ УСЛОВИЯ РАЗВИТИЯ МЕЛКОЙ МОТОРИКИ У ДЕТЕЙ 5-6 ЛЕТ В ПРОЦЕССЕ ПЛАСТИЛИНОГРАФИИ
}

\author{
Андросова Людмила Викторовна \\ студент 4 курса \\ Научный руководитель: Божедонова Анна Петровна \\ к.п.н., доцент кафедры дошкольного образования \\ Педагогический институт \\ ФГАОУ ВО «Северо-Восточный федеральный \\ университет им. М.К. Аммосова»
}

\begin{abstract}
Аннотация: В статье рассмотрены педагогические условия развития мелкой моторики у детей 5-6 лет в процессе пластилинографии. Затронуты проблемы повышения эффективности педагогической работы по развитию мелкой моторики детей. Проведено экспериментальное исследование в этом направлении.

Ключевые слова: дошкольный возраст, мелкая моторика, развитие мелкой моторики, педагогические условия, пластилинография.

\section{PEDAGOGICAL CONDITIONS FOR THE DEVELOPMENT OF FINE MOTOR SKILLS IN CHILDREN 5-6 YEARS OLD IN THE PROCESS OF PLASTICINOGRAPHY}

\section{Androsova Lyudmila Viktorovna Bozhedonova Anna Petrovna}

\footnotetext{
Abstract: The article discusses the pedagogical conditions for the development of fine motor skills in children aged 5-6 years in the process of plasticineography. The problems of improving the effectiveness of pedagogical work on the development of fine motor skills of children are touched upon. An experimental study has been conducted in this direction.

Key words: preschool age, fine motor skills, development of fine motor skills, pedagogical conditions, plasticineography.
} 
В настоящее время, когда наблюдается повышение требований к обучению детей в ДОО, актуализируется целый ряд психологопедагогических проблем, связанных с психомоторными возможностями детей дошкольного возраста. Одним из ориентиров готовности ребенка к школе, по положению ФГОС ДО, является развитие мелкой моторики, когда ребёнок может контролировать свои движения и управлять ими, обладает развитой потребностью бегать, прыгать и т.п. [4, с. 10].

Проблема повышения эффективности педагогической работы по развитию мелкой моторики детей 5-6 лет не теряет своей актуальности. Следует учесть, что отставание в развитии тонкой моторики рук у дошкольников затрудняет манипуляции различными мелкими предметами, препятствует овладению ими навыками самообслуживания, сдерживает развитие некоторых видов игровой деятельности [2, с. 11]. Все это обусловливает необходимость специальной целенаправленной работы по развитию тонких координированных движений рук.

Решение данной проблемы связано с поиском наиболее эффективных способов и средств обучения и воспитания, форм организации занятий изобразительным искусством с целью развития мелкой моторики рук.

Занятия пластилинографией позволяют всесторонне развивать личность ребёнка, его творческие способности, воображение. Дети получают знания, умения, навыки, ребёнок учится познавать мир осознавать себя и своё место в нём, расширять возможность изобразительной деятельности детей. Помимо этого, не стоит забывать и о таком аспекте, как подготовка кистей рук к занятию письмом, которое в наше время нередко начинается ещё до того, как ребёнок отправится учиться в школу.

Таким образом, выбор темы исследования объясняется актуальностью, востребованностью в педагогической среде и требует активной разработки ее методических основ.

Изучение и анализ психолого-педагогической литературы позволил выявить, насколько важно развитие мелкой моторики рук в дошкольном возрасте. Развитие мелкой моторики положительно влияет на формирование познавательных процессов: восприятия, памяти, мышления, внимания, воображения, а также на развитие речи и готовит к овладению навыками письма, что в будущем поможет избежать многих проблем школьного обучения. 
Было выяснено, что моторный уровень является базовым для развития высших психических функций, поэтому развитию мелкой моторики кисти руки должно уделяться серьезное внимание с самого раннего возраста, так как именно в этот период уровень интеллектуального развития очень сильно связан с уровнем развития двигательной активности [1, с. 62].

Помогая ребенку научиться координировать движения рук, соизмерять движения, мы развиваем его мозг. Выяснили, что именно внешняя стимуляция мозга помогает развитию мозговой активности и росту клеток организма.

Теоретическое обоснование базируется на работах Л.А. Венгера, А.В. Запорожца, М.М. Кольцовой, М. Монтессори, Н.П. Павловой и др. Изучение их работ позволило установить, что координальная значимость развития ребенка состоит в тесном единстве его психического и моторного развития.

Общее моторное отставание наблюдается у большинства современных детей, слабую руку дошкольника нужно и необходимо развивать.

Успех воспитания и обучения во многом зависит от того, какие методы и приемы использует педагог, чтобы донести определенное содержание, сформировать у них знания, умения и навыки, а также способности в определенном виде деятельности. Важную роль в этом играет именно пластилинография. Она способствует, в первую очередь, снятию мышечного напряжения и расслаблению, развивает детское воображение, художественное и пространственное мышление, будит фантазию, побуждает дошкольников к самостоятельности. При успешном овладении методикой рисования пластилином можно выполнять коллективные работы, создавать картины, оригинальные подарки для родителей и друзей [3].

Организация работы по созданию продуктов детского творчества в технике пластилинография позволяет решать не только практические, но и воспитательно-образовательные задачи, способствует всестороннему развитию личности ребенка. В игровой форме дети учатся выделять в своих художественных работах главный замысел и оттенять второстепенные детали. Дошкольники получают знания, умения и навыки, знакомятся с миром предметов в процессе частичного использования бросового материала. При этом расширяются возможности изобразительной деятельности детей, раскрываются методы обучения основным правилам, приемам и средствам композиции [5, с. 28]. Дети 5-6 лет уже понимают, что на занятии нужно внимательно слушать воспитателя, смотреть, что он показывает, а если 
спрашивает - отвечать. Но воспитатель по-прежнему использует элементы игры, игровые действия, чтобы заинтересовать детей, вызвать у них желание изобразить предмет.

Экспериментальной базой исследования является МБДОУ «Детский сад № 1 «Тугутчаан» с. Саскылах Анабарского улуса Республики Саха (Якутия), где приняли участие 20 детей старшего дошкольного возраста (экспериментальная и контрольная группы).

Для проведения диагностики, с целью выявления особенностей развития мелкой моторики в старшем дошкольном возрасте, нами были подобраны соответствующие методики: «Изучение уровня развития мелкой моторики» (автор А.В. Запорожец) [1]; методика «Домик» (автор Н.И. Гуткина) [4]; «Диагностика психомоторных навыков ребенка» (автор Л.С. Цветкова) [6].

По результатам проведения диагностики, мы выяснили, что общие уровни развития мелкой моторики рук у большинства детей экспериментальной группы находились на низком уровне - 50\%, тогда как в контрольной группе низкий уровень был выявлен у 30\% детей. Итак, мы обнаружили низкий уровень развития мелкой моторики рук у детей: большинство детей экспериментальной группы, которые плохо владеют карандашом, линии в основном кривые, неточные и слабые, у некоторых детей отмечается плохая координация движений кисти рук, слабость мышечной мускулатуры.

Таким образом, выявленные низкие результаты диагностики показали необходимость разработки методических рекомендаций по развитию мелкой моторики рук у детей 5-6 лет в процессе пластилинографии.

Содержание формирующего этапа эксперимента показало продуктивность данного подхода к повышению уровня развития мелкой моторики.

Учитывая важность проблемы по развитию мелкой моторики рук у детей 5-6 лет, нами был организован кружок «Дылача» (Солнце) - основной идеей которого является рисования картин - пластилином, пластилинография.

Цель программы кружка: развивать мелкую моторику рук, совершенствовать изобразительные умения, навыки и собственного творчества детей через продуктивную деятельность с применением нетрадиционных приемов работы с пластилином в технике пластилинографии. 
Работу по пластилинографии проводили в несколько этапов, на каждом из которых перед детьми ставили определённые задачи.

Подготовительный. Изучение авторских подходов к пластилинографии. Проведение начальной диагностики детей. Опрос родителей. Подготовка технических средств. Составление плана работы.

Практический. Организация и проведение непосредственной образовательной деятельности. Консультации для родителей. Обогащение развивающей среды в группе.

Итоговый. Оформление выставок детских работ. Анкетирование родителей. Итоговая диагностика детей. Выступление с опытом работы по данной теме перед воспитателями.

Основными средствами, которыми мы использовали в работе, являлись: художественные, наглядные и технические средства. Применение этих средств в работе позволило повысить активность и внимание детей, развить их воображение и фантазию, развить эстетические чувства. У дошкольников появляется устойчивый интерес к данному виду деятельности.

Особое внимание уделили и развивающей предметно-пространственной среде. Организация уголка изобразительной деятельности соответствует требованиям развивающей предметно-пространственной среды: гибкость, непрерывность, вариативность, открытость, интегрированность, эстетичность. Для этого мы выделили хорошо освещенное место. В распоряжении детей были следующие материалы: пластилин, дощечки для лепки, стеки, станок и мн. др. Мы соорудили и оформили полочку для демонстрации детских работ.

Проведенные нами занятия для детей 5-6 лет имели не повторяющиеся, разнообразные содержания и темы.

Большое значение для детей приобретал анализ работ в конце занятия, который организовывался в виде беседы. Задавали вопросы об изображенных поделках. Мы предлагали рассказать, что изображено, хорошо ли нарезана форма, какими способами сделали. Иногда оценку работам давали не сами авторы, а другие дети. В таком случае мы следили за тем, чтобы оценка была справедливой, тактичной, не обижала тех, кто выполнил работу. Для правильного анализа необходимо было выставлять все работы на стенде. На заключительном этапе, мы провели итоговую выставку детских работ.

Таким образом, дети начали стремиться делать красивые и качественные поделки, украшая их дополнительными деталями из различных 
материалов. Дошкольники быстро включались в предлагаемые задания эстетической направленности, задавали интересные вопросы по содержанию.

Хочется отметить, что одной из форм сотрудничества с родителями стало проведение детско-родительских занятий. Совместные занятия вызвали у детей чувство гордости за своих мам и пап, желание показать свои умения, находчивость и смекалку. Для повышения уровня компетентности родителей провели семинар-практикум для родителей «Растём, развиваемся, творим», провели мастер-класс на тему «Пластилиновая живопись в работе с дошкольниками». Проводимые с родителями различные консультации, мастер-классы, выставки совместного творчества дали свои результаты. Многие из родителей создали уголки творчества в домашних условиях.

Повторная диагностика на контрольном этапе исследования показала следующие результаты - дети экспериментальной группы: к концу занятий пальчики детей стали более ловкими, кисти рук - подвижными, гибкими, исчезла скованность движений, дети скорее выполняют сложные задания. У детей появился познавательный интерес, творческая активность. Дети с желанием с желанием стали заниматься пластилиновой живописью, свободно экспериментировали с художественными материалами и инструментами. У них стали развиты композиционные навыки, координация рук, мелкая моторика. Стали более самостоятельными, проявляли эмоциональный отклик на результат своей деятельности.

Со стороны родителей исходит инициатива - это создание благоприятных условий в группе, подбор необходимого материала и оборудования. Совместная деятельность с родителями также положительно влияет на воспитанников. Это подтверждают итоги участия в творческих конкурсах различного уровня.

Итак, проанализировав результаты своей педагогической деятельности, мы пришли к выводу, что опыт работы в данном направлении очень эффективен.

Currently, when there is an increase in the requirements for teaching children in preschool education, a number of psychological and pedagogical problems related to the psychomotor capabilities of preschool children are being actualized. One of the landmarks of a child's readiness for school, according to the position of the Federal State Educational Standard Before, is the development of fine motor 
skills, when a child can control his movements and control them, has a developed need to run, jump, etc.. [4, c. 10].

The problem of improving the effectiveness of pedagogical work on the development of fine motor skills of children 5-6 years old does not lose its relevance. It should be noted that the lag in the development of fine motor skills of hands in preschoolers makes it difficult to manipulate various small objects, prevents them from mastering self-service skills, hinders the development of some types of gaming activities [2, c. 11]. All this necessitates special purposeful work on the development of fine coordinated hand movements.

The solution to this problem is connected with the search for the most effective ways and means of teaching and upbringing, forms of organizing visual arts classes in order to develop fine motor skills of the hands.

Plasticine classes allow you to comprehensively develop the child's personality, his creative abilities, imagination. Children gain knowledge, skills, skills, the child learns to know the world to be aware of himself and its place in it, to expand the possibilities of children's visual activities. In addition, do not forget about such an aspect as the preparation of the hands for writing, which in our time often begins even before the child goes to school.

Thus, the choice of the research topic is explained by the relevance, demand in the pedagogical environment and requires active development of its methodological foundations.

The study and analysis of psychological and pedagogical literature revealed how important the development of fine motor skills of hands in preschool age is. The development of fine motor skills has a positive effect on the formation of cognitive processes: perception, memory, thinking, attention, imagination, as well as on the development of speech and prepares for mastering writing skills, which in the future will help to avoid many problems of schooling.

It was found out that the motor level is basic for the development of higher mental functions, therefore, the development of fine motor skills of the hand should be given serious attention from an early age, since it is during this period that the level of intellectual development is very strongly related to the level of development of motor activity [1, c. 62].

Helping a child to learn how to coordinate hand movements, to measure movements, we develop his brain. It was found out that it is the external stimulation of the brain that helps the development of brain activity and the growth of body cells. 
The theoretical justification is based on the works of L.A. Wenger, A.V. Zaporozhets, M.M. Koltsova, M. Montessori, N.P. Pavlova, etc. The study of their works allowed us to establish that the coordinating significance of a child's development consists in the close unity of his mental and motor development.

The general motor lag is observed in most modern children, the weak hand of a preschooler needs and needs to be developed.

The success of education and training largely depends on what methods and techniques the teacher uses to convey a certain content, to form their knowledge, skills and abilities, as well as abilities in a certain type of activity. Plasticinography plays an important role in this. It promotes, first of all, the removal of muscle tension and relaxation, develops children's imagination, artistic and spatial thinking, awakens imagination, encourages preschoolers to independence. If you successfully master the technique of drawing with plasticine, you can perform collective work, create paintings, original gifts for parents and friends [3].

The organization of work on the creation of products of children's creativity in the technique of plasticine allows solving not only practical, but also educational and educational tasks, contributes to the comprehensive development of the child's personality. In the form of a game, children learn to highlight the main idea in their artistic works and shade minor details. Preschoolers gain knowledge, skills and abilities, get acquainted with the world of objects in the process of partial use of discarded material. At the same time, the possibilities of children's visual activity are expanded, methods of teaching basic rules, techniques and means of composition are revealed [5, c. 28]. Children 5-6 years old already understand that in the classroom you need to listen carefully to the teacher, see what he shows, and if he asks, answer. But the educator still uses elements of the game, game actions to interest children, to make them want to portray the subject.

The experimental base of the study is MBDOU Kindergarten № 1 «Tugutchaan» in Saskylakh village of Anabar ulus of the Republic of Sakha (Yakutia), where 20 children of senior preschool age (experimental and control groups) took part.

For diagnostics, in order to identify the features of the development of fine motor skills in the senior preschool age, we selected the appropriate methods: «Study of the level of development of fine motor skills» (author A.V. Zaporozhets) [1]; the «House» technique (author N.I. Gutkina) [4]; «Diagnosis of psychomotor skills of a child» (author L.S. Tsvetkova) [6]. 
According to the results of the diagnostics, we found out that the overall levels of fine motor skills of the hands in most children of the experimental group were at a low level - 50\%, whereas in the control group a low level was detected in $30 \%$ of children. So, we found a low level of development of fine motor skills of the hands in children: most of the children of the experimental group who do not know how to use a pencil, the lines are mostly curved, inaccurate and weak, some children have poor coordination of hand movements, muscle weakness.

Thus, the revealed low diagnostic results showed the need to develop methodological recommendations for the development of fine motor skills of hands in children aged 5-6 years in the process of plasticineography.

The content of the formative stage of the experiment showed the productivity of this approach to improving the level of development of fine motor skills.

Considering the importance of the problem of the development of fine motor skills of hands in children 5-6 years old, we organized a circle «Dylacha» (the Sun) - the main idea of which is drawing pictures with plasticine, plasticineography.

The purpose of the circle program is to develop fine motor skills of hands, improve visual skills, skills and children's own creativity through productive activities using non-traditional methods of working with plasticine in the technique of plasticineography.

The work on plasticinography was carried out in several stages, at each of which children were assigned certain tasks.

Preparatory. The study of the author's approaches to plasticineography. Conducting initial diagnostics of children. Survey of parents. Preparation of technical means. Drawing up a work plan.

Practical. Organization and conduct of direct educational activities. Consultations for parents. Enrichment of the developing environment in the group.

The final one. Design of exhibitions of children's works. Parents' questionnaire. Final diagnosis of children. Presentation with work experience on this topic to educators.

The main means that we used in our work were: artistic, visual and technical means. The use of these tools in the work allowed to increase the activity and attention of children, to develop their imagination and imagination, to develop aesthetic feelings. Preschoolers have a steady interest in this type of activity.

Special attention was also paid to the developing subject-spatial environment. The organization of the corner of visual activity meets the requirements of the developing subject-spatial environment: flexibility, continuity, variability, 
openness, integration, aesthetics. To do this, we have allocated a well-lit place. The children had the following materials at their disposal: plasticine, modeling boards, stacks, a machine, and many others. We built and decorated a shelf for demonstrating children's works.

The classes we conducted for children 5-6 years old had non-repetitive, diverse contents and topics.

Of great importance for children was the analysis of works at the end of the lesson, which was organized in the form of a conversation. They asked questions about the depicted crafts. We offered to tell you what is depicted, whether the shape is well cut, what methods were used. Sometimes the works were evaluated not by the authors themselves, but by other children. In this case, we made sure that the assessment was fair, tactful, and did not offend those who did the work. For proper analysis, it was necessary to exhibit all the works on the stand.

At the final stage, we held a final exhibition of children's works.

Thus, children began to strive to make beautiful and high-quality crafts, decorating them with additional details from various materials. Preschoolers were quickly included in the proposed tasks of aesthetic orientation, asked interesting questions about the content.

I would like to note that one of the forms of cooperation with parents was the holding of parent-child classes. Joint classes aroused in children a sense of pride for their moms and dads, a desire to show their skills, resourcefulness and ingenuity. To increase the level of competence of parents, a workshop was held for parents "Growing, developing, creating", a master class was held on the topic "Plasticine painting in working with preschoolers". Various consultations, master classes, exhibitions of joint creativity conducted with parents have yielded their results. Many of the parents have created creative corners at home.

Repeated diagnostics at the control stage of the study showed the following results - the children of the experimental group: by the end of the lessons, the children's fingers became more dexterous, the hands became mobile, flexible, stiffness of movements disappeared, children are more likely to perform complex tasks. Children have a cognitive interest, creative activity. Children with a desire with a desire began to engage in plasticine painting, freely experimented with artistic materials and tools. They have developed compositional skills, hand coordination, fine motor skills. They became more independent, showed an emotional response to the result of their activities. 
The initiative comes from the parents - it is the creation of favorable conditions in the group, the selection of the necessary material and equipment. Joint activities with parents also have a positive effect on pupils. This is confirmed by the results of participation in creative competitions of various levels.

So, after analyzing the results of our pedagogical activity, we came to the conclusion that the experience of working in this direction is very effective.

\section{Список литературы}

1. Аксенова М.Н. Развитие тонких движений пальцев рук у детей дошкольного возраста / М.Н. Аксенова // Дошкольное воспитание. - 2010. - № 8 . $-62 \mathrm{c}$.

2. Любина Г.А. Рука развивает мозг / Г.А. Любина. О.В. Желонкина // Ребёнок в детском саду. - 2010. - № 6. - 11 с.

3. Муковоз Т.А. Использование нетрадиционной техники «пластилинография» в формировании изобразительной деятельности дошкольников [Электронный ресурс] / T.А. Муковоз.- 2012. - Режим доступа: http: // www.ivalex.vistcom.ru/konsultac (дата обращения: 15.12.2021).

4. Светлова И.Е. Развиваем мелкую моторику и координацию движений рук / И.Е. Светлова. - М. : Изд-во Эксмо, 2013. - 10 с.

5. Тихомирова О.Ю. Пластилиновая картина для работы с детьми дошкольного и младшего школьного возраста / О.Ю. Тихомирова, Г.А. Лебедева. - М. : Мозаика-синтез, 2011. - 28 с.

6. Цветкова Л.С. Методика диагностического нейропсихологического обследования детей / Л.С. Цветкова. - М. : Речь, 2007. - 154 с. 